\title{
UPAYA MENINGKATKAN KEMAMPUAN ANAK USIA DINI MENGENAL WARNA
}

\author{
Edi Hendri Mulyana ${ }^{1}$, Istikhoroh Nurzaman ${ }^{2}$, Nur Asifa Fauziyah ${ }^{3}$ \\ ${ }^{1}$ Program Studi PGPAUD UPI Kampus Tasikmalaya \\ ${ }^{2}$ Program Studi PGPAUD UPI Kampus Tasikmalaya \\ ${ }^{3}$ Program Studi PGPAUD UPI Kampus Tasikmalaya
}

Email: edihm@upi.edu

(Received: Mei 2017; Accepted: Mei 2017; Published: Juni 2017)

\begin{abstract}
This research is motivated by the problem of cognitive development of 4 years old children in recognizing color. The purpose of this study is to provide treatment to children so that children have an increase in the ability to recognize the color. The research method used is case study using qualitative approach. The subject of this research is one child aged 4 years in group A Play Group Ceria Kecamatan Cibeureum Tasikmalaya City. The results of this study children have increased in recognizing the color, especially the basic color after 16 treatments given by researchers.
\end{abstract}

Keywords : Case Study, Recognizing Color, Treatment.

\begin{abstract}
ABSTRAK
Penelitian ini dilatarbelakangi oleh permasalahan perkembangan kognitif anak usia 4 tahun dalam mengenal warna. Tujuan dari penelitian ini adalah untuk memberikan treatment kepada anak agar anak memiliki peningkatan kemampuan dalam mengenal warna. Metode penelitian yang digunakan adalah studi kasus dengan menggunakan pendekatan kualitatif. Subjek penelitian ini satu orang anak berusia 4 tahun di kelompok A Kober Ceria Kecamatan Cibeureum Kota Tasikmalaya. Hasil dari penelitian ini anak mengalami peningkatan dalam mengenal warna terutama warna dasar setelah diberikan 16 treatment oleh peneliti.
\end{abstract}

Kata Kunci: Studi Kasus, Mengenal Warna, Treatment.

\section{PENDAHULUAN}

Fari Ulfah (2016) menyatakan bahwa Pendidikan Anak Usia Dini (PAUD) merupakan suatu upaya pembinaan yang ditujukan untuk anak usia 0 sampai 6 tahun dalam mengoptimalkan pertumbuhan dan perkembangan anak, agar anak memiliki kesiapan dalam memasuki pendidikan selanjutnya. Sedangkan kategori anak usia dini adalah anak dengan rentang usia 0 sampai 6 tahun. Usia dini merupakan usia awal pertumbuhan dan perkembangan paling penting dalam sejarah hidup manusia, karena masa ini merupakan dasar untuk pertumbuhan dan perkembangan pada masa selajutnya. Beberapa ahli tentang psikologi anak usia dini memandang bahwa periode usia dini merupakan periode yang sangat penting, sehingga dibutuhkan penanganan sedini mungkin. Maria Montessori (dalam Hurlock, 1978) berpendapat bahwa usia 3 sampai 6 tahun merupakan periode sensitive, yaitu masa peka anak usia dini, dimana suatu fungsi tertentu perlu dirangsang dan diarahkan 
sehingga perkembangannya tidak terhambat. Pada rentang usia 0 sampai 6 tahun setiap anak memiliki tugas-tugas perkembangan dalam tahapan usia tertentu. Tugas-tugas perkembangan anak usia dini harus dialami oleh setiap anak usia dini pada umumnya. Namun tentunya tidak semua anak dapat mengalami tugas perkembangan dengan baik, ada yang cepat namun ada juga yang lambat, bahkan sebagian anak tidak mengalami tugas perkembangan dengan baik atau bahkan terlewat. Hal ini tentunya diperlukan pengawasan dan bimbingan secara tepat untuk mengatasi kesulitan anak dalam memenuhi tugas perkembangan anak usia dini.

Kemampuan mengenal warna merupakan salah satu aspek dalam kemampuan kognitif. Salah satu kemampuan anak usia dini dalam masa perkembangannya adalah mampu mengenal warna. Kemampuan mengenal warna merupakan aspek perkembangan kognitif yang harus dialami oleh setiap anak. Kemampuan mengenal warna dapat merangsang indra penglihatan anak usia dini untuk melihat objek-objek di lingkungan sekitarnya secara lebih peka.

Menurut Peraturan Menteri Pendidikan dan Kebudayaan Republik Indonesia No. 137 tahun 2014 tentang standar nasional anak usia dini lampiran 1 standar isi tentang tingkat pencapaian perkembangan anak usia 12 sampai 18 bulan dalam lingkup perkembangan kognitif, anak mampu mengenal beberapa warna dasar, yaitu warna merah, biru, kuning, dan hijau. Namun dalam kenyataannya di kelompok A Kober Ceria kecamatan Cibeureum kota Tasikmalaya masih terdapat anak usia 4 tahun masih kurang dalam mengenal warna dasar tersebut. Pada masa awal penerimaan siswa, setiap anak mengalami tes kemampuan awal mengenal warna, dan didapatkan hasil yang berbeda dari setiap anak. Selama satu semester awal guru memberikan beberapa treatment untuk meningkatkan kemampuan anak dalam mengenal warna. Hasilnya terdapat beberapa anak mengalami peningkatan kemampuan dalam mengenal warna terutama warna dasar, dan hanya ada satu orang anak yang masih kurang dalam mengenal warna. Setelah guru membandingkan beberapa anak yang satu usia atau usianya hampir mendekati, dari 5 anak hanya ada satu anak yang memiliki hambatan yakni anak tersebut belum mengenal warna, terutama warna dasar. Setiap kali guru menunjukkan warna, anak tersebut selalu kurang tepat dalam menjawab warna benda tersebut. Setelah beberapa kali hal ini sering terjadi, peneliti mencoba melakukan tes buta warna atau yang disebut dengan tes ishihara untuk mengetahui kondisi penglihatan anak tersebut.

Buta warna merupakan suatu kelainan pada penglihatan, hal ini disebabkan karena ketidakmampuan sel-sel kerucut dalam retina mata yang mengalami kelemahan atau kerusakan permanen, sehingga mata tidak dapat merespon warna dengan baik. Untuk mengetahui kondisi kesehatan mata anak tersebut, peneliti menggunakan tes buta warna melalui tes ishihara yang sudah lazim dilakukan oleh dokter. Tes ishihara ini berupa plat atau lembaran berisi titik-titik lingkaran dengan berbagai warna dan bentuk, sehingga ketika diperlihatkan kepada orang yang mengalami buta warna tidak akan melihat perbedaan warna tersebut, berbeda halnya dengan orang normal. Melalui tes buta warna tersebut, didapatlah hasilnya bahwa anak tersebut tidak buta warna. Hal ini tentunya memerlukan penanganan khusus terhadap masalah yang dihadapi oleh anak tersebut. Dalam kondisi situasi ini peneliti memfokuskan untuk mengungkap fenomena tersebut melalui sebuah penelitian dengan judul "Upaya Meningkatkan Kemampuan Anak Usia Dini Mengenal Warna".

Adapun rumusan masalah dalam penelitian ini adalah sebagai berikut:

1. Apa faktor penyebab kesulitan anak dalam mengenal warna?

2. Bagaimana upaya meningkatkan kemampuan anak dalam mengenal warna?

3. Bagaimana hasil upaya meningkatkan kemampuan anak dalam mengenal warna?

Penelitian ini dilakukan tentunya memiliki tujuan, berikut di bawah ini merupakan tujuan penelitian: 
1. Untuk mengetahui faktor penyebab kemampuan anak dalam mengenal warna

2. Untuk mengetahui upaya meningkatkan kemampuan anak dalam mengenal warna

3. Untuk mengetahui hasil upaya meningkatkan kemampuan anak dalam mengenal warna

Berdasarkan tujuan penelitian di atas, penelitian ini dapat memberikan manfaat sebagai berikut:

1. Kegunaan teoritis

Sebagai dasar penelitian selanjutnya agar lebih baik lagi dalam upaya meningkatkan kemampuan anak usia dini mengenal warna

2. Kegunaan praktis

a. Bagi peneliti

Sebagai data riil hasil penelitian, selanjutnya dapat digunakan sebagai acuan untuk melakukan penelitian selanjutnya terkait masalah perkembangan anak dalam mengenal warna.

b. Bagi guru

Sebagai pedoman dalam meningkatkan kemampuan anak usia dini mengenal warna

c. Bagi anak.

Sebagai pedoman agar anak mampu melakukan tugas perkembangan dengan baik dalam mengenal warna.

\section{TINJAUAN PUSTAKA}

\subsection{Teori Perkembangan Kognitif}

Piaget

Menurut teori Piaget, anak-anak membangun pemahaman tentang dunia melalui empat tahap perkembangan kognitif. Keempat tahapan tersebut memiliki kriteria usia tertentu serta cara berpikir yang berbeda-beda dalam mengenal dunia. Keempat tahapan perkembangan kognitif menurut Piaget adalah sebagai berikut:

1) Tahap sensori-motor (usia 0-2 tahun)

Pada tahap ini anak mampu
mengenal dunianya melalui
pengorganisasian terhadap pengalaman
sensoris, misalnya melalui pendengaran

dan penglihatan dengan tindakantindakan fisik dan motorik.

2) Tahap praoperasional (usia 2-7 tahun)

Pada tahapan ini anak mulai menggambarkan dunia melalui bahasa atau perkataan serta gambar-gambar, melebihi tindakan sederhana dari informasi sensoris dan tindakan fisik.

3) Tahap operasional konkret (usia 7-11 tahun)

Pada tahap ini anak mampu menalar berbagai objek yang ada di sekitarnya, serta mampu berpikir konkret. Pada tahapan ini anak belum bisa diberikan pemahaman tentang pemikiranpemikiran abstrak, melainkan harus diberikan pemahaman spesifik atau logis.

4) Tahap operasional formal (usia 11-15 tahun)

Tahap operasional formal ini akan terus berlangsung hingga dewasa. Pada tahapan ini lebih dari sekedar berpikir konkret dan logis. Bahkan anak sudah mampu berpikir abstrak, mengenai pandangan terhadap suatu objek dan mulai memikirkan pandangan hidup ke depan, serta mampu memecahkan masalah melalui hipotesis untuk diuji kebenarannya.

\subsection{Teori Kognitif Sosiobudaya Vigotsky}

Teori kognitif Vigotsky lebih menekankan pada perkembangan kognitif sosiobudaya, dimana pengetahuan anak dibangun melalui interaksi sosial dan budaya lingkungan. Ia berpendapat bahwa perkembangan memori, serta penalaran mencakup kegiatan untuk menggunakan temuan-temuan di masyarakat, bersama teman sebaya, dan orang yang memberikan pengaruh terhadap perkembangan bahasa, sistem matematika, serta sistem memori. Dalam praktiknya, sebuah budaya mengantarkan terhadap cara anak memecahkan masalah, misalnya anak dapat menggunakan mesin hitung sebagai alat untuk memecahkan persoalan matematika, sementara budaya lain dalam memecahkan 
persoalan matematika atau hitungan dengan menggunakan manik-manik atau biji-bijian.

\subsection{Teori Pemrosesan Informasi}

Pada teori ini, menggambarkan bahwa individu memanipulasi, memonitor, dan menyusun strategi terhadap informasi yang diperoleh. Teori pemrosesan informasi tidak memiliki tahapan-tahapan sesuai dengan usia seperti teori kognitif Piaget, namun menurut teori ini individu secara bertahap mengembangkan kapasitasnya untuk memproses informasi yang diterima, sehingga pengetahuan dan keterampilan yang diperoleh akan lebih kompleks. Robert Siegler (dalam Santrock, 2012) mengungkapkan bahwa "kegiatan berpikir merupakan suatu bentuk pemrosesan informasi". Hal ini dapat digambarkan bahwa ketika seorang individu menangkap sebuah informasi yang dituliskan kedalam sebuah sandi, kemudian menyimpannya di memori, dan mengeluarkan kembali sebagai proses memberikan informasi, itu tandanya seorang individu sedang berpikir. Aspek penting dari perkembangan kognitif adalah cara mempelajari strategi yang tepat untuk memroses sebuah informasi. Menurut Baddeley (dalam Kristina Vann, 2015) "working memory refers to the amount of information that a child can hold in mind and manipulate at any given time" artinya memori yang bekerja tergantung pada jumlah informasi yang didapat oleh pikiran manusia pada waktu tertentu.

\subsection{Psikologi Komunikasi}

Menurut Fisher (dalam Rakhmat, 2005) bahwa dalam psikologi komunikasi terdapat empat ciri pendekatan psikologi pada komunikasi, yaitu :

1) Penerimaan stimuli secara indrawi

2) Proses yang mengantarai stimuli dan respons

3) Prediksi respons

4) Peneguhan respons

Dalam hal ini, psikologi melihat komunikasi dimulai dengan masuknya data terhadap organ-organ penginderaan manusia. Stimuli tersebut dapat berupa orang, pesan, suara, warna, dan segala hal yang dapat mempengaruhi manusia. Stimuli tersebut kemudian diolah dalam sebuah kotak hitam yang tidak pernah kita ketahui. Hasil dari pengolahan stimuli tersebut dapat berupa kesimpulan tentang suatu keadaan, misalnya jika seseorang tersenyum, bertepuk tangan, kemudian melompatlompat, itu tandanya orang tersebut sedang bahagia.

1) Memori Jangka Pendek

Memori jangka pendek merupakan suatu wadah untuk memroses informasi. Informasi akan masuk ke dalam memori jangka pendek pada saat informasi diterima oleh memori sensori. Manusia dalam mengingat informasi dalam memori jangka pendek mempunyai keterbatasan rata-rata memiliki kemampuan mengingat dalam memori jangka pendek pada saat otak manusia dalam keadaan sadar terhadap informasi tersebut. Memori jangka pendek ini akan hilang setelah 20 detik. Kehilangan informasi tersebut dapat dicegah melalui proses pengulangan. Proses pengulangan informasi tersebut diulang-ulang sehingga dalam jangka waktu lebih dari 20 detik informasi akan disimpan dalam memori jangka panjang, sehingga pada saat diungkap kembali informasi tersebut akan tetap ada dalam ingatan.

2) Memori Jangka Panjang

Memori jangka panjang merupakan memori yang tersimpan dalam kurun waktu hitungan hari, minggu, bulan, bahkan tahun. Para ahli di bidang kognitif telah membagi memori jangka panjang menjadi 3 kategori, diantaranya:

a) Declarative knowledge (pengetahuan deklaratif)

Pengetahuan deklaratif merupakan suatu pengetahuan faktual untuk mengetahui tentang "apa". Misalnya pengetahuan tentang suatu tempat, danau Toba berada di Pulau Sumatera, atau mengetahui tentang nama warna misalnya anak mengetahui nama warna dari suatu benda.

Menurut Sandhofer dan Smith (2001, hlm. 602) mengungkapkan "color words 
are taught by presenting a single object and asking "What color is this?" This type of input emphasizes color words as category labels". Untuk anak usia dini dalam hubungannya dengan mengingat tentang warna dibutuhkan suatu pertanyaan tentang "warna apa ini?", dengan demikian akan memfokuskan anak pada suatu konsep atau penamaan sebuah warna, dengan demikian jika anak sering diberikan pertanyaan seperti demikian, maka anak akan terbiasa untuk memberikan jawaban tentang warna dari pertanyaan yang diajukan.

b) Procedural knowledge (pengetahuan prosedural)

Pengetahuan prosedural merupakan suatu pengetahuan tentang "bagaimana" yakni cara mempelajari prosedur suatu aktivitas, misalnya anak belajar tentang cara menggosok gigi dan cara memakai baju.

c) Conditional knowledge (pengetahuan kondisional)

Pengetahuan kondisional merupakan suatu pengetahuan tentang "bagaimana dan mengapa". Dalam hal ini menggunakan pengetahuan deklaratif dan prosedural secara tepat.

Memori jangka panjang juga dibedakan menjadi memori eksplisit dan memori implisit. Memori eksplisit merupakan informasi atau ingatan tentang masa lalu yang pernah dialami dan masih disadari keberadaannya. Sedangkan memori implisit merupakan memori yang sudah tidak disadari tetapi masih berpengaruh terhadap aktivitas sehari-hari seperti mengancingkan baju, membuka pintu, memakai kaos kaki, dan kegiatan lainnya. Menurut Sprenger (dalam Davis, 2007, hlm. 49) mengatakan bahwa 'explicit memory is broken down into two categories. The first is semantic...the second memory under explicit memory is episodic memory...' artinya bahwa memori eksplisit terbagi menjadi dua bagian yaitu yang pertama adalah memori semantik yaitu memori yang berkaitan dengan informasi secara faktual. Kedua adalah memori episodik. Memori episodik ini menggambarkan tentang ingatan sebuah tempat yang pernah dikunjungi sebelumnya serta tentang apa yang dipelajari di tempat tersebut.

\subsection{Pengertian Warna dan Jenis-jenis Warna}

Warna merupakan pantulan cahaya dari benda-benda sehingga warna merupakan unsur pertama yang terlihat oleh mata dari suatu benda. Menurut Sulasmi (dalam Hesti, 2013) warna merupakan sebuah unsur keindahan dalam seni yang terlihat secara visual dan dapat memberikan kesan perbedaan bentuk fisik dari suatu benda.

Kemampuan mengenal warna merupakan aspek kognitif yang terdapat dalam Peraturan Menteri Pendidikan dan Kebudayaan Republik Indonesia No. 137 tahun 2014 tentang standar nasional anak usia dini lampiran 1 standar isi tentang tingkat pencapaian perkembangan anak usia 12 sampai 18 bulan bahwa anak memiliki tugas perkembangan untuk mengenal beberapa warna dasar diantaranya warna merah, kuning, biru, dan hijau. Menurut Sulasmi (dalam Hesti, 2013)"menurut teori Brewster, warna dasar terdiri dari tiga warna yaitu warna merah, kuning, dan biru yang juga merupakan lingkaran warna, teori ini dilihat dari pendidikan seni rupa". Sementara menurut ahli psikolog warna dasar terdiri empat warna yang merupakan warna kesatuan yaitu warna merah, kuning, hijau, dan biru. Ketiga warna primer yang masih digunakan pada saat ini adalah merah, kuning, dan biru. Merah seperti warna darah, kuning seperti warna telur, dan biru seperti langit atau laut.

Ada beberapa rumus pencampuran warna menurut Sulasmi (1989) terdapat dalam tabel sebagai berikut. 
Tabel 1. Rumus pencampuran warna teori munsell

\begin{tabular}{|c|c|c|c|}
\hline \multirow[b]{2}{*}{ No } & \multirow[b]{2}{*}{$\begin{array}{c}\text { Jenis } \\
\text { warna }\end{array}$} & \multicolumn{2}{|c|}{ Warna } \\
\hline & & $\begin{array}{c}\text { Campuran } \\
\text { warna }\end{array}$ & $\begin{array}{c}\text { Hasil } \\
\text { pencampuran } \\
\text { warna }\end{array}$ \\
\hline \multirow{3}{*}{1} & \multirow{3}{*}{$\begin{array}{l}\text { Warna } \\
\text { primer }\end{array}$} & & Merah \\
\hline & & & Kuning \\
\hline & & & Biru \\
\hline \multirow{3}{*}{2} & \multirow{3}{*}{$\begin{array}{c}\text { Warna } \\
\text { sekunder }\end{array}$} & $\begin{array}{c}\text { Merah + } \\
\text { Kuning }\end{array}$ & Jingga \\
\hline & & $\begin{array}{c}\text { Merah + } \\
\text { Biru }\end{array}$ & Ungu \\
\hline & & $\begin{array}{c}\text { Kuning + } \\
\text { Biru }\end{array}$ & Hijau \\
\hline \multirow{6}{*}{3} & \multirow{6}{*}{$\begin{array}{l}\text { Warna } \\
\text { tersier }\end{array}$} & $\begin{array}{c}\text { Jingga + } \\
\text { Merah }\end{array}$ & $\begin{array}{c}\text { Jingga } \\
\text { kemerahan }\end{array}$ \\
\hline & & $\begin{array}{c}\text { Jingga }+ \\
\text { Kuning }\end{array}$ & Jingga keunguan \\
\hline & & $\begin{array}{l}\text { Ungu + } \\
\text { Merah }\end{array}$ & Ungu kemerahan \\
\hline & & Ungu + Biru & Ungu kebiruan \\
\hline & & $\begin{array}{l}\text { Hijau + } \\
\text { Kuning }\end{array}$ & Hijau kekuningan \\
\hline & & Hijau + Biru & Hijau kebiruan \\
\hline
\end{tabular}

1) Alat Permainan Edukatif (APE) sebagai Media Pembelajaran untuk Anak Usia Dini

Alat Permainan Edukatif (APE) merupakan media pembelajaran yang sengaja dirancang untuk kepentingan pendidikan sebagai alat permainan yang mengandung unsur pendidikan. Misalnya, boneka tangan, balok, puzzle, dan alat permainan lain yang mengandung unsur pendidikan. APE ini berbeda dengan alat permainan biasa yang tidak digunakan sebagai media pembelajaran, karena alat permainan edukatif atau APE ini dapat menimbulkan kesenangan, daya khayal, dan imajinasi tersendiri bagi anak usia dini. Hal ini tentunya sangat menunjang bagi perkembangan anak usia dini (Zaman dkk. 2008).

2) Pembelajaran Sains untuk Anak Usia Dini

Pembelajaran sains di negara Denmark sudah diterapkan untuk anak usia dini, di Indonesiapun sudah mulai dimasukkan ke dalam pembelajaran di PAUD. Pernyataan ini sesuai dengan ungkapan dari Kementrian Sosial Denmark (dalam Stig Brostom, 2015).
In the Danish curriculum the theme "nature and nature phenomenon", which is one of six themes in the curricula, it is stated, that "children should act and get first experiences with the nature's, animal, plants and materials, and get experiences with causes and connections.

Pada saat ini cukup banyak perkembangan penelitian yang menerangkan tentang tingginya motivasi anak usia dini terhadap ilmu pengetahuan atau pembelajaran sains. "When talking with adults, young children ask between 76 and 95 information seeking question...young children, however, are specially curious about the natural world". Secara intrinsik anak tertarik pada dunia di sekitar mereka, sebagaimana banyaknya pertanyaan yang diajukan oleh anak usia dini kepada orang dewasa. Anak-anak sering mengajukan pertanyaan tanpa henti mengenai suatu informasi yaitu 76 hingga 95 rata-rata pertanyaan setiap anak per jam dari sekitar 3 pertanyaan setiap 2 menit. Beberapa pertanyaan mereka melibatkan ilmu pengetahuan dan teknologi fisik. Penerangan tersebut menunjukkan bahwa anak begitu penasaran tentang ilmu pengetahuan dan alam. (Trundle, K \& Sackes, M. 2015).

"In trying to understand the world around them (which includes biological and physical sciences), young children form their own concepts" artinya anak usia dini memahami dunia sains di sekitar mereka yakni dari konsep mereka sendiri (Jackman, H). Pemikiran anak usia dini tentang konsep dasar sains tidak sama dengan pemikiran orang dewasa. Mereka memahami sifat benda dan peristiwa dari perspektif dan pengalaman mereka sendiri (Akerson, dkk. 2011). Sebagai orang 
dewasa, kita memiliki kemampuan untuk menganalisa bentuk hipotesis dan membuat kesimpulan.

\section{METODE}

Jenis penelitian ini merupakan penelitian deskriptif studi kasus dengan menggunakan pendekatan kualitatif. Furchan (2004) mengemukakan bahwa "penelitian deskriptif dirancang untuk memperoleh informasi tentang status gejala saat penelitian dilakukan. Penelitian ini diarahkan untuk menetapkan sifat suatu situasi pada waktu penyelidikan itu dilakukan". Studi kasus merupakan suatu penelitian yang dilakukan untuk mengungkap suatu kasus yang dianggap sebagai masalah, penyimpangan, atau hambatan yang dialami oleh seorang individu, kelompok atau suatu kebijakan program (Sukmadinata, 2012). Metode penelitian deskriptif studi kasus ini bertujuan untuk mengungkap masalah yang dihadapi oleh seorang individu secara mendalam serta berusaha untuk memecahkan masalah tersebut.

Penelitian berawal dari studi pendahuluan yang dilakukan di lapangan. Pada saat studi pendahuluan di lapangan peneliti menemukan suatu masalah untuk dilakukan penelitian lebih lanjut. Peneliti mulai merancang rumusan masalah berdasarkan fenomena yang belum diketahui penyebabnya serta merumuskan tujuan dari penelitian tersebut. Dilihat dari sudut pandang peneliti terhadap permasalahan yang terjadi di lapangan, peneliti berusaha mengaitkan fakta-fakta yang terjadi di lapangan dengan beberapa teori dasar untuk dijadikan sebagai bahan pertimbangan pada saat peneliti membuat instrumen penelitian. Langkah selanjutnya adalah penentuan metode penelitian, yaitu suatu cara atau jalan yang akan ditempuh oleh peneliti untuk menyelesaikan permasalahan yang terjadi di lapangan. Penentuan subjek penelitian dan pihak-pihak yang terlibat dalam penelitian ditentukan sebelum peneliti merancang instrumen penelitian. Dalam merancang sebuah instrumen, peneliti mengaitkan beberapa teori dan kebijakan pemerintah yang berhubungan dengan permasalahan yang terjadi di lapangan. Peneliti mulai turun ke lapangan setelah instrumen selesai dirancang dan divalidasi oleh ahli. Peneliti mengumpulkan data dengan melakukan interaksi dengan subjek penelitian serta pihakpihak lain yang terlibat dalam penelitian, yaitu guru kelas dan orang tua. Data yang sudah terkumpul selanjutnya dilakukan analisis berdasarkan teori penunjang untuk memperoleh hasil penelitian dan pembahasan yang ditulis ke dalam sebuah laporan penelitian. Maka dari itu didapatkan kesimpulan berupa fakta yang terjadi di lapangan untuk menjawab rumusan masalah.

Partisipan dalam penelitian ini adalah subjek penelitian yang menjadi sumber utama dalam penelitian untuk dilakukan treatment sebagai upaya bimbingan dan koseling peneliti terhadap masalah yang dihadapi oleh subjek penelitian.

Subjek penelitian ini adalah anak laki-laki berusia 4 tahun dengan inisial $M$, yang merupakan salah satu siswa kelas A di Kober Ceria Kp. Negla kidul Gunung Daning RT 005 RW 006 Kelurahan Setiajaya Kecamatan Cibeureum Kota Tasikmalaya Provinsi Jawa Barat.

Data yang diperoleh dari penelitian ini merupakan deskripsi pencapaian anak dari hasil upaya yang dilakukan peneliti terhadap subjek penelitian dalam upaya meningkatkan kemampuan anak usia dini mengenal warna.

Menurut Moleong (dalam Arikunto, 2013) bahwa sumber data dalam penelitian kualitatif adalah berupa tulisan secara narasi atau dalam bentuk kata-kata yang dapat menggambarkan makna secara tersirat.

Data yang diperoleh dari penelitian ini pada umumnya adalah data kualitatif, namun tidak menutup kemungkinan data kuantitatif akan muncul setelah dilakukannya penelitian secara terus menerus sampai jenuh.

Sumber data yang diperoleh untuk penelitian ini berasal dari subjek penelitian, yaitu anak yang sedang diteliti berikut orang tuanya, serta lembaga pendidikan atau sekolah beserta seluruh organisasi di dalamnya yang berhubungan dengan subjek penelitian atau anak yang sedang diteliti. 
Dalam penelitian ini teknik pengumpulan data dilakukan melalui dua teknik, yaitu:

1) Observasi

Teknik observasi yang dilakukan oleh peneliti adalah observasi partisipatif, dimana peneliti secara langsung ikut serta dalam aktivitas anak yang sedang diamati sebagai sumber data. Melalui observasi partisipatif ini peneliti akan lebih merasakan situasi yang sedang dialami oleh anak, sehingga peneliti akan mendapatkan data yang lebih lengkap, akurat, serta sampai mengetahui makna dari setiap tingkah laku anak yang sedang diamati.

2) Wawancara

Teknik wawancara ini dilakukan pada saat studi pendahuluan, selanjutnya peneliti menggunakan teknik wawancara semiterstruktur (semistructure interview). Jenis wawancara ini termasuk kedalam kategori in-depth interview, dimana wawancara ini merupakan teknik wawancara yang lebih terbuka dibandingkan teknik wawancara terstruktur. Tujuannya agar narasumber lebih terbuka dalam mengemukakan pendapat, serta idenya (Sugiyono, 2015).

Instrumen lembar observasi yang dirancang oleh peneliti memuat beberapa media rancangan peneliti yang digunakan sebagai upaya untuk meningkatkan kemampuan anak mengenal warna. Adapun material dan langkah-langkah yang dilakukan untuk membuat media tersebut adalah sebagai berikut

a) Kertas origami berwarna merah, kuning, biru, dan hijau.

b) Puzzle gambar buah tomat dan stroberi untuk mengenalkan warna merah. Puzzle gambar tokoh kartun doraemon dan gambar mobil untuk mengenalkan warna biru. Bahan yang digunakan berasal dari kertas dus bekas berukuran besar, kemudian digunting membentuk persegi panjang mengikuti ukuran gambar buah tomat, stroberi, tokoh kartun doraemon, dan gambar mobil yang telah diberi pola. Gambar diberi pola garis kotak-kotak menjadi 5 kotak, kemudian digunting sesuai garis pola tersebut. Potongan gambar tersebut ditempelkan ke dus kemudian dijiplak mengikuti bentuk pola. Setelah ditempel baru pola tersebut dilapisi oleh lakban agar lebih tahan lama jika terkena air. Kemudian puzzle dapat disusun diatas alas persegi panjang yang tadi telah dibuat dengan diberi sisi seperti figura.

c) Miniatur gunung meletus untuk mengenalkan warna merah. Bahan yang digunakan adalah kertas koran dan kertas bekas yang sudah tidak terpakai. Kertas tersebut direndam dalam air dan didiamkan selama 2 malam agar seluruh tekstur kertas menjadi hancur dan lembek. Setelah direndam, kertas tersebut diperas dan dimasak dengan campuran sedikit air dan tepung kanji, kemudian aduk hingga merata. Setelah adonan kertas dan tepung kanji menjadi dingin, maka adonan tersebut dapat dibentuk menjadi miniatur gunung meletus. ditengah-tengah miniatur gunung meletus tersebut diletakkan kaleng atau botol bekas kemudian bungkus hingga membentuk seperti gunung. Langkah selanjutnya dikeringkan kemudian siap dipakai.

d) Playdough berwarna kuning. Bahan yang digunakan untuk membuat playdough adalah tepung terigu yang dicampur dengan air secukupnya, kemudian diberi pewarna makanan berwarna kuning agar terlihat menarik. Supaya playdough tersebut awet dan tidak bau, maka dicampurkan sedikit sabun cair kemudian diaduk kembali. Playdoughpun siap untuk dimainkan.

e) Gelembung sabun berwarna kuning. Alat dan bahan yang digunakan 
adalah mangkuk kecil sebagai wadah, sabun colek, air, dan pewarna makanan. Bahan-bahan tersebut dicampurkan secukupnya kemudian diaduk hingga menghasilkan gelembung yang sempurna. Alat untuk meniup gelembung sabun tersebut terbuat dari kawat besi yang dibentuk bulat dan diliti oleh benang.

f) Miniatur hujan warna biru di dalam botol. Alat dan bahan yang digunakan adalah botol bekas minuman berukuran $600 \mathrm{ml}$ yang dimasukkan air sampai $3 / 4$ bagian. Untuk $1 / 4$ bagian lagi diisi dengan minyak goreng kemudian dimasukkan pewarna berwarna biru. Maka reaksi hujan warna biru terjadi setelah didiamkan beberapa menit.

g) Balon karet berwarna hijau untuk mengenalkan warna hijau.

h) Cairan tepung berwarna hijau. Bahan yang digunakan adalah tepung yang diberi sedikit air kemudian diaduk hingga rata. Setelah cairan dibagi menjadi beberapa bagian kemudian diberi warna pada masing-masing wadah dengan warna kuning dan biru. Untuk menghasilkan warna hijau, cairan tersebut dicampurkan menjadi satu. Cairan tepung tersebut digunakan sebagai bahan untuk kegiatan bermain finger painting.

Analisis data dalam penelitian kualitatif ini dilakukan pada saat peneliti melakukan tahapan pengumpulan data melalui teknik observasi serta wawancara. Hasil dari observasi dan wawancara tersebut menghasilkan sebuah hipotesis, sehingga untuk menguji kebenarannya maka peneliti secara terus-menerus melakukan pengumpulan data berulang kali sampai jenuh atau sampai hasilnya tetap sama setelah dilakukan analisis data, sehingga hipotesis tersebut dapat berkembang menjadi sebuah teori.

peneliti melakukan antisipasi sebelum melakukan reduksi data. Reduksi data dilakukan pada saat data sudah terkumpul, untuk kemudian dipilih data mana yang akan diambil dan sebagian data yang tidak diperlukan dipisahkan atau dibuang. Meruduksi data berarti merangkum pokok-pokok dari data hasil penelitian, serta memfokuskan pada hal-hal penting dari data tersebut.

Reduksi data dalam penelitian kualitatif pada akhirnya akan menghasilkan pencapaian tujuan untuk menghasilkan sebuah temuan. Pada saat reduksi data dilakukan, hal-hal asing yang ditemukan oleh peneliti hendaknya dijadikan perhatian untuk diteliti lebih lanjut sampai titik jenuh.

Selanjutnya

peneliti

melakukan display data setelah reduksi data dilakukan. Display data yang dilakukan peneliti dapat berupa narasi atau pendeskripsian data hasil temuan yang didapatkan. Agar display data dapat terlihat lebih jelas, peneliti dapat menggambarkan hasil penelitian ke dalam uraian bentuk grafik, matrik, network, dan chart kemudian dijelaskan hubungan antara uraian gambar hasil penelitian tersebut secara naratif. Jika hipotesis penelitian sudah didukung oleh data yang diperoleh selama di lapangan, maka hipotesis tersebut sudah terbukti, sehingga peneliti menghasilkan teori atau temuan dari hipotesis tersebut, untuk selanjutnya didisplaykan dalam laporan akhir penelitian.

Langkah ketiga dalam penelitian kualitatif setelah peneliti melakukan display data adalah verifikasi data untuk membuat kesimpulan. Hal ini dilakukan secara bertahap, artinya peneliti menyimpulkan hasil dari penelitian yang bersifat sementara yang masih memerlukan pengecekkan data kembali di lapangan, jika hasilnya sudah menunjukan data yang konsisten maka diperoleh kesimpulan final, kemudian disusun atau diajukan rekomendasi, jika memungkinkan penelitian ini untuk dikembangkan menjadi sebuah teori untuk diterapkan pada kasus yang sama pada objek yang lain. 


\section{HASIL DAN PEMBAHASAN \\ 4.1 Faktor Penyebab Kesulitan Anak Dalam Mengenal Warna}

Berdasarkan data yang diperoleh dari hasil wawancara bersama orang tua ananda M, bahwa faktor yang mempengaruhi kesulitan anak dalam mengenal warna adalah kurangnya pemberian rangsangan terhadap anak dalam mengenal warna. Orang tua jarang mengenalkan warna sejak anak masih kecil, semua hanya terjadi mengalir begitu saja. Alasan ini terjadi karena ibu dari ananda $\mathrm{M}$ ini memiliki tiga orang anak yang usianya masih terlalu dekat. Ibu dari tiga anak ini mengalami kerepotan dan pada akhirnya mempengaruhi terhadap rangsangan pendidikan terutama dalam mengenalkan warna kepada anak sejak usia dini. Orang tua hanya memberikan edukasi lewat permainan di handphone saja, sehingga anak mengalami kesulitan dalam melalui tahap perkembangannya terutama dalam mengenal warna. Padahal menurut teori kognitif sosiobudaya Vigotsky, dengan adanya interaksi antara anak dengan lingkungan atau budaya sekitar maka akan membantu anak dalam memecahkan permasalahan yang tidak akan didapatkan hanya melalui gadget saja.

\subsection{Upaya Meningkatkan Kemampuan Anak Usia Dini Mengenal Warna}

Pada tanggal 19 April 2017 peneliti melakukan observasi terhadap kemampuan anak dalam mengenal warna pada saat dilakukan treatment oleh peneliti. Treatment di hari ke-1 peneliti mengenalkan warna merah menggunakan media kertas origami, peneliti menegaskan kepada anak bahwa warna kertas tersebut adalah merah, setelah 5 detik anak ditanya kembali tentang warna kertas tersebut, anak dapat mengingat serta menjawab bahwa warna kertas tersebut berwarna merah. Pada 5 detik berikutnya anak masih mengingat, namun pada 5 detik berikutnya anak tidak fokus sehingga dilakukan pengulangan pertanyaan oleh peneliti, kemudian anak menjawab bahwa warna kertas tersebut adalah warna merah. Fakta ini sesuai dengan kajian teori tentang memori jangka pendek. Anak akan mengingat dengan mudah pada 20 detik pertama setelah mendapatkan informasi.

Treatment kedua pada hari ke-1 peneliti mengajak anak untuk bermain puzzle gambar buah tomat dan gambar buah stroberi, kemudian peneliti menerangkan kepada anak bahwa warna puzzle tersebut adalah merah. Anak diberikan kesempatan untuk bermain bongkar pasang puzzle tersebut. Setelah 5 menit, peneliti bertanya kepada anak tentang warna puzzle tersebut, kemudian anak menjawab bahwa warna puzzle tersebut adalah merah. Ini menunjukkan bahwa anak mampu mengingat warna merah setelah dikenalkan 5 menit. Pada 5 menit berikutnya anak ditanya kembali tentang warna puzzle tersebut, dan anak masih mengingatnya dengan menjawab bahwa warna puzzle tersebut adalah merah, begitu juga pada 5 menit berikutnya anak masih mampu mengingat.

Treatment ketiga pada hari ke-1 peneliti mengajak anak untuk bermain sains percobaan gunung meletus menggunakan alat permainan edukatif miniatur gunung meletus. Anak diberikan kesempatan untuk mencampurkan soda kue, cuka, dan pewarna makanan berwarna merah ke dalam miniatur gunung meletus. Peneliti menjelaskan kepada anak bahwa pewarna yang dimasukkan tadi warnanya adalah merah. Kemudian anak diberikan kesempatan untuk mengamati reaksi yang terjadi. Setelah lava berwarna merah keluar dari miniatur gunung meletus, anak menunjukkan ekspresi senang dan terusmenerus mengulangi kegiatan tersebut. Setelah satu jam anak bermain miniatur gunung meletus, peneliti menanyakan kembali tentang warna lava yang keluar dari gunung tersebut, hasilnya anak mampu mengingat dan menyebutkan bahwa lava yang keluar dari gunung tersebut berwarna merah. Fakta ini sesuai dengan perkembangan penelitian yang dilakukan 
oleh Trundle \& Sackes. Bahwa anak usia dini mempunyai motivasi yang tinggi terhadap ilmu pengetahuan atau pembelajaran sains, karena anak dapat memperoleh pengetahuan berdasarkan pengalamannya.

Kegiatan berikutnya pada hari ke-1, peneliti bekerjasama dengan orang tua, sehingga orang tua dapat membimbing anaknya mengenalkan warna merah melalui kegiatan sehari-sehari di rumah serta dengan menggunakan media yang telah digunakan oleh peneliti sebelumnya. Pada hari berikutnya peneliti melakukan recalling dan hasilnya anak masih mengingat warna merah. Artinya, kemampuan anak dalam mengenal warna selama satu hari menunjukkan bahwa anak mampu menyimpan informasi ke dalam memori jangka panjang.

Hari ke-2 peneliti mengenalkan warna kuning kepada anak melalui media kertas origami berwarna kuning, peneliti menegaskan kepada anak bahwa warna kertas origami tersebut berwarna kuning. Setelah 5 detik, peneliti bertanya kepada anak tentang warna kertas origami tersebut, dan anak menjawab bahwa warna kertas origami tersebut adalah kuning. Ini menunjukkan kemampuan ingatan anak dalam detik kelima setelah dikenalkan warna kuning. Pada 5 detik berikutnya anak masih mengingat warna kertas origami tersebut berwarna kuning, dan pada 5 detik berikutnya sampai detik ke 20 anak masih mengingat bahwa warna kertas origami tersebut berwarna kuning. Seperti yang telah dibahas pada hari sebelumnya, bahwa anak mampu menyimpan informasi ke dalam memori jangka pendek.

Treatment kedua yang dilakukan oleh peneliti pada hari ke-2 yaitu mengajak anak bermain playdough berwarna kuning. Peneliti menegaskan kepada anak bahwa warna playdough tersebut adalah berwarna kuning. Anak diberikan kesempatan untuk bermain playdough dan membuat bentuk bebas sesuai dengan imajinasi anak. Anak berhasil menuangkan imajinasinya dengan membuat bentuk orang atau tubuh manusia dari playdough tersebut. Setelah 5 menit anak ditanya oleh peneliti tentang warna playdough tersebut. Anak menjawabnya pink, kemudian peneliti menjelaskan kembali bahwa warna playdough tersebut warnanya kuning, bukan pink. Setelah 5 menit anak bermain playdough peneliti bertanya kembali kepada anak tentang warna playdough tersebut, anak menjawabnya benar bahwa warna playdough tersebut adalah kuning. Pada 5 menit berikutnya, anak ditanya kembali tentang warna playdough tersebut, tetapi anak tidak menjawab dan tidak merespon pertanyaan yang diajukan oleh peneliti karena anak terlihat fokus tertarik bermain playdough. Anak baru menjawab ketika ditanya kedua kalinya oleh peneliti dengan bantuan peringatan oleh ibunya. Anak menjawab dengan benar bahwa warna playdough tersebut berwarna kuning. Pada 5 menit berikutnya anak langsung menjawab dengan penuh kegembiraan ketika ditanya oleh peneliti tentang warna playdough tersebut, kemudian anak menjawab warnanya adalah kuning.

Treatment ketiga di hari ke-2 peneliti mengajak anak keluar rumah untuk bermain gelembung sabun. Peneliti telah menyediakan alat dan bahan untuk membuat gelembung sabun. Anak diberikan kesempatan untuk mencampurkan bahanbahan untuk membuat gelembung sabun dengan bimbingan peneliti. Anak mulai mencampurkan air, sabun cair, dan pewarna makanan berwarna kuning. Anak sengaja diberikan kesempatan mencampurkan bahan-bahannya sendiri agar anak mengalami sendiri proses yang terjadi. Peneliti menjelaskan kepada anak bahwa pewarna makanan tersebut berwarna kuning. Anak mulai mencampurkan bahan, kemudian setelah racikan selesai dibuat, anak diajak keluar rumah mencari tempat yang lebih luas untuk bermain gelembung sabun. Anak diberikan kesempatan oleh peneliti untuk bermain bebas bersama teman-temannya yang kebetulan pada saat 
itu ikut menyaksikan. Setelah satu jam anak bermain gelembung sabun bersama temantemannya. Peneliti bertanya kepada anak tentang warna gelembung sabun tersebut. Anak langsung merespon dengan cepat bahwa warna gelembung sabun tersebut adalah kuning, seterusnya anak bercerita kepada peneliti tentang pengalaman yang dilakukan oleh anak pada saat bermain gelembung sabun di luar bersama temantemannya, anak terlihat sangat tertarik dengan permainan tersebut.

Kegiatan berikutnya pada hari ke-2, peneliti bekerjasama dengan orang tua, sehingga orang tua dapat membimbing anaknya mengenalkan warna kuning melalui kegiatan sehari-sehari di rumah serta dengan menggunakan media yang telah digunakan oleh peneliti sebelumnya. Pada hari berikutnya peneliti melakukan recalling dan hasilnya anak masih mengingat warna kuning.

Pada hari ke-3 peneliti memberikan treatment untuk mengenalkan warna biru kepada anak. Pertama, peneliti mengenalkan warna biru kepada anak menggunakan kertas origami berwarna biru. Peneliti menegaskan kepada anak bahwa warna kertas origami tersebut adalah biru. Setelah 5 detik peneliti bertanya kepada anak tentang warna kertas origami tersebut. Anak menjawab bahwa warna kertas tersebut berwarna biru, ini menandakan bahwa anak masih mengingat informasi yang diberikan oleh peneliti. Pada 5 detik berikutnya hingga detik ke 20 anak masih mengingat bahwa warna kertas tersebut berwarna biru.

Treatment kedua pada hari ke-3 peneliti mengajak anak bermain bongkar pasang puzzle dari gambar tokoh kartun doraemon dan gambar mobil berwarna biru. Peneliti menjelaskan kepada anak bahwa warna puzzle tersebut berwarna biru. Anak diberikan kesempatan untuk bermain sendiri tanpa bantuan orang lain. Setelah 5 menit, peneliti bertanya kepada anak tentang warna puzzle tersebut. Anak menjawab dengan benar bahwa puzzle tersebut berwarna biru, hal ini menandakan bahwa anak masih mengingat informasi yang diberikan oleh peneliti pada 5 menit yang lalu. Pada 5 menit berikutnya anak ditanya kembali tentang warna puzzle tersebut kemudian anak menjawab bahwa puzzle tersebut berwarna hijau, berarti anak sudah lupa tentang informasi warna biru yang disampaikan oleh peneliti 5 menit yang lalu. Kemudian peneliti menjelaskan kembali dengan menunjukkan 2 kertas yang berwarna hijau dan biru, peneliti menjelaskan kepada anak perbedaan dari kedua benda tersebut yaitu ada kertas yang berwarna biru, dan ada kertas yang berwarna hijau. Setelah 5 menit peneliti menanyakan kembali kepada anak tentang warna puzzle yang tadi dimainkan oleh anak kemudian anak menjawab bahwa puzzle tersebut berwarna biru. Pada 5 menit berikutnya peneliti menanyakan kembali tentang warna puzzle tersebut, dan anak masih menjawab bahwa warnanya hijau. Kemudian peneliti menjelaskan kembali tentang warna biru melalui kertas origami. Peneliti mengajak anak bermain melipat kertas dari kertas berwarna biru membentuk seekor kupu-kupu. Peneliti menjelaskan kepada anak bahwa warna kupu-kupu dari kertas origami tersebut berwarna biru. Hal ini dilakukan untuk mempertahankan ingatan anak terhadap benda yang berwarna biru. Setelah 5 menit anak melipat kertas, peneliti menanyakan kembali tentang warna kupu-kupu dari kertas origami tersebut, kemudian anak menjawab dengan benar bahwa warna kupu-kupu tersebut adalah biru, begitu juga dengan puzzle anak menjawab bahwa puzzle tersebut berwarna biru.

Treatment ketiga di hari ke-3, peneliti mengajak anak bermain hujan warna menggunakan media botol air mineral. Anak diberikan kesempatan untuk mencampurkan bahan-bahan yaitu air putih, minyak goreng, dan pewarna makanan berwarna biru ke dalam botol berukuran $600 \mathrm{ml}$ yang sudah disediakan oleh peneliti. Peneliti menjelaskan kepada anak tentang 
warna yang dimasukkan oleh anak tersebut, bahwa warnanya adalah biru. Anak diberikan kesempatan untuk mengamati reaksi yang terjadi setelah bahan-bahan tersebut dimasukkan ke dalam botol, maka terjadilah hujan warna biru di dalam botol tersebut. Anak terlihat sangat fokus dan senang dengan pembelajaran sains tersebut. Setelah satu jam anak bermain dengan percobaan sains tersebut, peneliti bertanya kepada anak tentang warna cairan hujan di dalam botol tersebut, kemudian anak dapat menjawab dengan benar bahwa warna cairan hujan tersebut adalah biru. Hal ini menandakan bahwa anak masih mengingat informasi yang disampaikan oleh peneliti setelah satu jam.

Kegiatan berikutnya pada hari ke-3, peneliti bekerjasama dengan orang tua, sehingga orang tua dapat membimbing anaknya mengenalkan warna biru melalui kegiatan sehari-sehari di rumah serta dengan menggunakan media yang telah digunakan oleh peneliti sebelumnya. Pada hari berikutnya peneliti melakukan recalling dan hasilnya anak masih mengingat warna biru.

Pada hari ke-4, peneliti memberikan treatment untuk mengenalkan warna hijau kepada anak. Pertama, peneliti menunjukkan kertas origami berwarna hijau kepada aank dan menegaskan bahwa kertas origami tersebut berwarna hijau. setelah 5 detik anak diberikan pertanyaan tentang warna kertas origami tersebut, kemudian anak menjawab bahwa kertas origami tersebut adalah hijau. hal ini menandakan bahwa anak masih mengingat informasi yang diberikan oleh peneliti selama 5 detik. Setiap 5 detik berikutnya anak ditanya kembali tentang warna kertas origami tersebut, sampai pada detik ke 20 anak masih mampu mengingat informasi tentang warna kertas tersebut warnanya adalah hijau.

Treatment kedua di hari ke-4 peneliti mengajak anak untuk bermain meniup balon karet berwarna hijau yang sudah disediakan oleh peneliti. Peneliti menjelaskan kepada anak bahwa warna balon karet tersebut adalah hijau. Anak diberikan kesempatan untuk meniup balon karet tersebut dan memainkannya. Setelah 5 menit anak diberikan pertanyaan oleh peneliti tentang bagaimana warna balon tersebut, kemudian spontan anak menjawab warna balon tersebut adalah biru. Tentu saja hal ini menunjukkan bahwa anak lupa tentang warna balon tersebut. Peneliti berusaha mengingatkan kembali dan menunjukkan balon mana yang warnanya hijau dan balon mana yang warnanya biru. Setelah 5 menit kemudian anak ditanya kembali, hingga anak dapat menjawab dan mengingat bahwa warna balon tersebut adalah hijau. Pada 5 menit berikutnya anak ditanya kembali tentang warna balon tersebut kemudian anak menjawab warna balon tersebut itu biru, tentunya jawaban anak masih kurang tepat. Peneliti memberikan upaya untuk mengulang kembali ingatan 5 menit yang lalu dengan cara menjelaskan kembali bahwa warna balon tersebut adalah hijau, sambil peneliti mengajak anak untuk mengumpulkan benda yang ada di rumah yang warnanya sama dengan balon karet tersebut yaitu warna hijau. Setelah anak selesai mengumpulkan benda berwarna hijau, 5 menit kemudian anak ditanya kembali tentang warna balon yang dimainkan oleh anak tadi, anak menjawab bahwa warna balon tersebut adalah hijau. pada 5 menit berikutnya peneliti menanyakan hal yang sama tentang warna balon hijau yang tadi dimainkan oleh anak, lagi-lagi anak menjawab balon tersebut warnanya biru. Peneliti melakukan upaya untuk mengingatkan kembali warna hijau dengan cara menunjukkan balon warna hijau warnanya sama dengan bendabenda di rumah yang telah dikumpulkan oleh anak warnanya mirip dengan balon tersebut yaitu hijau. setelah 5 menit peneliti bertanya kepada anak tentang warna balon tersebut, dan anak masih mengingat bahwa warna balon tersebut adalah hijau.

Treatment ke-3 di hari keempat, peneliti mengajak anak untuk bermain 
mencampurkan warna kuning dan biru yang akan menghasilkan warna hijau. Bahan yang digunakan oleh peneliti adalah cairan tepung yang diberi pewarna. Terlebih dahulu anak diberikan kesempatan untuk membuat racikannya sendiri dengan bimbingan peneliti. Anak mulai mencampurkan cairan warna kuning dengan biru, kemudian menghasilkan warna baru yaitu hijau. peneliti menegaskan kepada anak bahwa hasil pencampuran warna kuning dengan biru yang dilakukan oleh anak adalah warna hijau. Kemudian anak dipersilahkan untuk bermain finger painting di atas alas karton putih yang telah disediakan oleh peneliti. Setelah satu jam anak bermain finger painting anak ditanya kembali tentang warna hasil pencampuran antara kuning dan biru, kemudian anak menjawab warna hijau. Hal ini menandakan bahwa anak mampu mengingat informasi yang telah diberikan oleh peneliti selama satu jam yang lalu.

Kegiatan berikutnya pada hari ke-4, peneliti bekerjasama dengan orang tua, sehingga orang tua dapat membimbing anaknya mengenalkan warna biru melalui kegiatan sehari-sehari di rumah serta dengan menggunakan media yang telah digunakan oleh peneliti sebelumnya. Pada hari berikutnya peneliti melakukan recalling dan hasilnya anak masih mengingat warna hijau.

Satu minggu setelah dilakukan treatment, peneliti melakukan recalling atau pengecekkan kembali terhadap kemampuan anak dalam mengingat warna, hasilnya anak dapat mengingat warna merah dan kuning dengan lancar namun untuk warna biru dan hijau masih sering tertukar. Solusi yang diberikan oleh peneliti adalah mengajak anak menonton video mengenal warna, serta peneliti bekerjasama dengan orang tua untuk mengenalkan kembali warna biru dan hijau melalui kegiatan sehari-hari di rumah. Hasilnya anak mampu mengingat keempat warna tersebut setelah peneliti melakukan recalling pada minggu berikutnya.
4.3 Hasil upaya meningkatkan kemampuan anak usia dini mengenal warna

Berdasarkan data hasil observasi dan wawancara terhadap guru dan orang tua siswa, peneliti memperoleh hasil berupa peningkatan kemampuan anak dalam mengenal warna. Adapun hasil dari upaya meningkatkan kemampuan anak usia dini digambarkan melalui grafik di bawah ini:

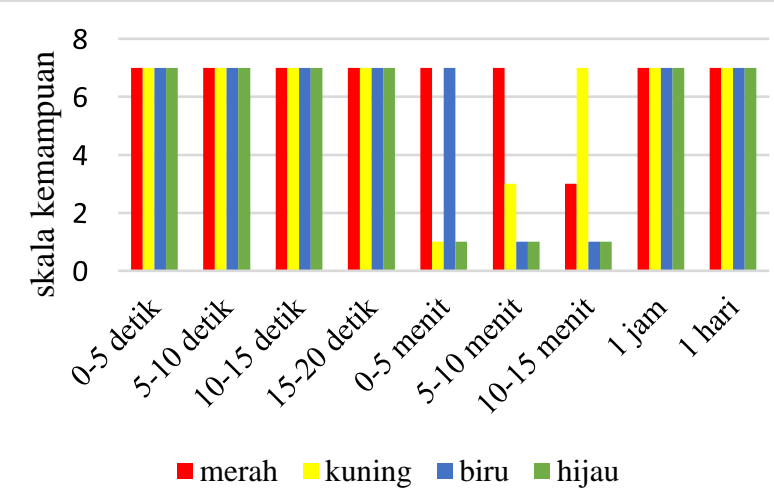

Gambar 1. Grafik hasil upaya meningkatkan kemampuan anak usia dini mengenal warna Skala kemampuan:

0-1 : Anak cenderung lupa

0-3 : Anak menjawab dengan ragu-ragu

0-7 : Anak mampu mengingat

Dari gambar 4.6 di atas, dapat disimpulkan bahwa anak mampu mengingat setiap informasi yang diberikan oleh peneliti berupa pengetahuan tentang warna merah, kuning, biru, dan hijau melalui treatment dengan menggunakan Alat Permainan Edukatif (APE) dalam rentang waktu 0-5 detik, 5-10 detik, 10-15 detik, 15-20 detik, 0-5 menit, 5-10 menit, 10-15 menit, 1 jam, hingga satu hari. Namun ada sedikit kesulitan yang dialami oleh anak di menit ke 5 sampai menit ke 15 bahwa anak mengalami kesulitan mengingat atau lupa dan ragu-ragu untuk menyebutkan warna yang ditanyakan oleh peneliti. Namun pada jam berikutnya anak mampu mempertahankan ingatan atau informasi yang diperoleh melalui permainan sains yang diberikan oleh peneliti, sehingga dapat dikatakan bahwa anak mampu menyimpan informasi pada memori jangka panjang. 


\section{KESIMPULAN}

Berdasarkan hasil penelitian yang diperoleh peneliti melalui observasi dan wawancara, peneliti akhirnya dapat memberikan kesimpulan berupa jawaban dari rumusan masalah. Berdasarkan hasil analisis temuan penelitian, bahwa faktor penyebab kesulitan anak dalam mengenal warna disebabkan karena kurangnya motivasi dan dorongan berupa rangsangan tentang pengetahuan mengenal warna terutama dari orang tua sejak anak masih kecil. Kurangnya media atau alat permainan edukatif yang diberikan oleh orang tua juga memberikan pengaruh negatif karena anak hanya dibiarkan bermain melalui gadget atau hand phone saja. Akibatnya anak kurang berinteraksi secara langsung dengan permainan-permainan edukasi atau pembelajaran sains untuk meningkatkan kemampuan anak dalam mengenal warna.

Upaya atau treatment yang diberikan oleh peneliti dalam mengatasi masalah tersebut adalah melalui pengenalan warna menggunakan media berbasis edukasi atau yang disebut dengan alat permainan edukatif seperti kertas origami, puzzle, playdough, serta pembelajaran sains seperti miniatur gunung meletus, gelembung sabun, hujan warna, dan pencampuran warna untuk finger painting.

Hasil dari pemberian treatment tersebut anak mengalami peningkatan kemampuan dalam mengenal warna, terutama warna merah, kuning, hijau, dan biru.

\section{SARAN}

Hasil dari penelitian ini dapat diterapkan di lembaga sekolah untuk membantu guru dalam menyelesaikan masalah yang sama terhadap subjek yang lain yang memiliki permasalahan sama dengan penelitian ini. Bagi para orang tua, penelitian ini juga dapat dijadikan sebagai pedoman deteksi dini untuk mencegah terjadinya kesulitan anak dalam mengenal warna melalui pembelajaran intens di rumah dengan mengenalkan setiap warna dari benda di sekitar anak, serta penelitian ini dapat dijadikan sebagai solusi terhadap permasalahan yang dihadapi oleh anak terutama permasalahan dalam mengenal warna.

Bagi para peneliti yang akan melakukan penelitian tentang peningkatan kemampuan anak usia dalam mengenal warna, penelitian ini dapat dijadikan sebagai referensi atau pedoman untuk melakukan penelitian terhadap subjek yang lain yang akan diteliti. Jika penelitian ini diterapkan pada subjek yang lain, maka penelitian ini akan menjadi sebuah teori atau cara baru untuk memberikan solusi dalam mengatasi permasalahan anak terutama dalam mengatasi masalah kesulitan anak dalam mengenal warna.

\section{DAFTAR PUSTAKA}

Akerson, V. dkk. (2011). The importance of teaching and learning nature of science in the early childhood years. Journal Science Education Technology, 538, (20), hlm. 537-549.

Brostom, S. (2015). Science in early childhood education. Journal of Education and Human Development, 4, (2(1)), hlm. 108-124.

Arikunto, S. (2013). Prosedur penelitian suatu pendekatan praktik. Jakarta: PT Rineka Cipta.

Aqib, Z. (2015). Model-model, media, dan strategi pembelajaran kontekstual (inovatif). Bandung: Yrama Widya.

Creswell, J. (2015). Riset pendidikan perencanaan, pelaksanaan, dan evaluasi riset kualitatif \& kuantitatif. Yogyakarta: Pustaka Pelajar.

Davis, S. (2007). Learning styles and memory. Institute for Learning Styles Journal, 1, 46-51.

Fadlillah, M. dkk. (2014). Edutainment pendidikan anak usia dini. Jakarta: Kencana.

Furchan, A. (2004). Pengantar penelitian dalam pendidikan. Yogyakarta: Pustaka pelajar. 
Gaines, K \& Curry, Z. The inclusive classroom: the effects of color on learning and behavior. Journal of Family \& Consumer Sciences Education, 29 (1), hlm.46-57.

Hernia, H. (2013). Kemampuan mengenal warna pada anak usia 4-5 tahun di TK segugus III kecamatan panjatan kabupaten kulon progo. (Skripsi) Fakultas Pendidikan Universitas Yogyakarta.

Jackman, H. (1999). Early education curriculum a child's connection to the world. United States: Delmar.

Muthmainnah. (2016, 16 Desember). Bimbingan dan konseling anak usia dini. [Online]. Diakses dari http://staff.uny.ac.id/sites/default/files/pe ndidikan/Muthmainnah/BK\%AUD.pdf

Rakhmat, J. (2005). Psikologi komunikasi. Bandung: Rosdakarya

Sandhofer, C \& Smith, L. (2001). Why children learn color and size words so differently: evidence from adults learning of artificial terms. Journal of Experimental Psychology : General, 130, (4), hlm. 600-620.

Sugiyono. (2015). Metode penelitian pendidikan. Bandung: Alfabeta.

Santrock, J.W. (2012). Life-span development. Jakarta: Erlangga.

Sukmadinata, N. S. (2012). Metode penelitian pendidikan. Bandung: Rosdakarya.

Trundle, K \& Sackes, M. (2015). Research in early childhood science education. New York: Springer.

Vann, K. (2015). Early childhood education teacher perspectives, effective program and impact on cognitive development. New York: Nova.

Wiyani, N.A. (2002). Konsep dasar PAUD. Yogyakarta: Gava media.

Yin, R. K. (2015). Studi kasus desain \& metode. Jakarta. PT Rajagrafindo Persada.

Yin, R. K. (2009). Case study research design and methods. Amerika Serikat: Sage.
Zaman, B. dkk. (2008). Media dan sumber belajar TK. Penerbit Universitas Terbuka. 